\title{
SOLOVJOV, DOSTOJEVSKIJ A ZÁKLADY MORÁLKY ${ }^{1}$
}

\section{Solovyov, Dostoevsky and the Foundations of Morality}

Keywords: Dostoevsky, literary personages, moral foundations theory, morality, Solovyov

Contact: Masarykova univerzita; 415780@mail.muni.cz

Ruský filosof Vladimir Sergejevič Solovjov, zakladatel proudu svébytné ruské náboženské filosofie, představil v roce 1897 ve svém díle Ospravedlnění dobra poměrně moderní etický systém. Jeho zřejmě nejoriginálnější součástí je už dříve rozpracované pojetí dějin (Solovjov 1997a; Solovjov 2004), v němž spojuje vědecké poznatky o evoluci s křest’anskou vírou, podobně, jako to o několik desetiletí později učinil také francouzský filosof Pierre Teilhard de Chardin (Brabec 2008). Stejně jako filosofie dějin také Solovjovova etika reflektovala poznatky tehdejší vědy a zakládala lidskou morálku na určitých emocích. V pojetí samotné evoluce a stejně tak v pojetí základů morálky Solovjov reagoval na Darwina, avšak v mnohém k němu byl kritický (Solovjov 2002: 8-22).

Jako ,základy mravnosti“" stanovuje Solovjov tři emoce: stud, lítost (soucit) a zbožnost. Stud upravuje vztahy člověka k „nižší přírodě“ (ke zvířatům, rostlinám, neživé přírodě) a pramení z něj askeze. Lítost řídí chování člověka nejen vůči nižší přírodě, ale především vưči sobě rovným, tedy vůči ostatním lidem, je počátkem altruismu. Zbožnost vede člověka v jednání vůči tomu, co jej přesahuje, zakládá zbožnou úctu. Přitom každá ze tř́i emocí je neredukovatelná na druhé dvě, ale všechny ostatní city (např. láska) jsou redukovatelné na tyto tři základy. V jiném smyslu jsou však tři emoce na sobě závislé; aby byl člověk mravný, nesmí být ani jedna z nich potlačena.

Teorie základů morálky dodnes nevyšly z módy, naopak; na konci 20. století zažily svůj boom s rozvojem morální psychologie. Zřejmě nejvýznamnějším současným

\footnotetext{
1 Tato studie vznikla na Masarykově univerzitě v rámci projektu Slavistická badatelská dílna číslo MUNI/A/0900/2019 podpořeného z prostředků účelové podpory na specifický vysokoškolský výzkum, kterou poskytlo MŠMT v roce 2020.
} 
představitelem je Jonathan Haidt, který postupně představil morálním filosofům dokonce šest emocí či hodnot a jejich protějšků, které morálku zakládají. Tato myšlenka, podle níž je morálka redukovatelná na několik základních emocí či hodnot, sbližuje jinak rozdílné filosofy, jako je Solovjov, podle něhož jsou nám tyto základy dány Bohem a jsou vrozené a podle něhož je sama morálka univerzální, a Haidt, který proponuje „racionalistické“ vysvětlení morálky a její kulturní podmíněnost (Haidt 2012). Mohli bychom uvést mnohé další - současné či dávno zemřelé - myslitele, kteří se Solovjovem sdílejí tento př́stup založený na psychologii (Prokof'ev 2017). Snad nebude troufalé, když se na chvíli obrátíme $\mathrm{k}$ filosofii zády a budeme hledat př́klady této teorie $\mathrm{v}$ literatuře, konkrétně ve velkých románech $\mathrm{F}$. M. Dostojevského, Solovjovova současníka a př́tele.

Dostojevskij je oprávněně zkoumán psychology a psychologizujícími badateli na poli literární vědy, a protože základy morálky v lidské přirozenosti s psychologií úzce souvisejí, bude snad i naše volba př́kladů oprávněná. Rovněž hledání souvislostí mezi dílem Solovjova a Dostojevského je opodstatněné. Tito myslitelé byli současníci, a i přes značný věkový rozdíl můžeme tvrdit, že to byli také přátelé. Byli si ideově blízcí a v jejich dílech je patrný jejich vzájemný kontakt (Kostalevsky 1997). I když Dostojevskij nebyl v pravém smyslu filosof (nezanechal po sobě celistvý filosofický systém a dokonce ani jediný filosofický traktát), filosofii miloval a měl na ni také značný vliv (Berd’ajev, 2000). Samotné jeho postavy jsou filosofové, např́íklad Ivan Karamazov (Bulgakov 1998: 261). Nechceme tvrdit, že Dostojevskij přijímal Solovjovův etický systém (nebo že jej odmítal), nechceme tvrdit ani to, že byl zastáncem teorie morálních základů, ale jakýsi psychologický profil postav jeho románů je založen právě na absenci důležitého citu, nebo naopak na typizaci, kdy konkrétní postava zastupuje určitou emoci a představuje vybranou složku společnosti, díky čemuž jsou jeho díla nenahraditelným zdrojem pro naše zkoumání.

Už Platón (Phaedr. 253e-254e; $R$. 435d-436a) rozlišoval v lidské duši tři složky - rozum, vznětlivost a žádostivost, prričemž převaha jedné z nich udávala charakter člověka, ale i celé obce. Zatímco však v Platónově teorii bylo žádoucí, aby jednotlivé složky duše byly v hierarchii a rozumná složka převládala nad ostatními, u Solovjova i u Dostojevského je žádoucí, aby byly city (a př́padně také rozum) v harmonii, respektive aby nebyla žádná složka potlačena, nebo naopak aby nepotlačovala druhé, protože city, které leží v základech morálky, jsou rovnocenné a stejně dobré. Solovjov explicitně formuluje tezi, že člověk je morální jen tehdy, pokud jsou u něj př́tomny všechny tři tyto city, a popisuje situace, kdy jeden z citů chybí a zdánlivě morální chování se tak převrací ve zlo. Své teze podporuje i uměleckým vyjádřením v beletristicko-filosofickém díle Tři rozhovory, jehož součástí je také Krátká legenda 
o Antikristu (Solovjov 1997b). Podobné př́klady najdeme také v Dostojevského románech.

\section{Bratři Karamazovi, tři emoce a obraz společnosti}

Bratři Karamazovi, vrcholné dílo Dostojevského, demonstrují výše uvedené principy v úplnosti. Nezř́idka jsou bratři srovnáváni na základě emocí, které jim chybí či které u nich převažují. František Kautman (Kautman 2004: 160) je charakterizuje takto: „Ivan je intelekt, Dmitrij je srdce, cit, Aljoša je na citu založená víra.“ Tato „terminologie“ neodpovídá zcela filosofické terminologii Solovjova, ale jen proto, že Dostojevského dílo je beletristické, nezobecňuje, líčí jemné nuance, a může proto tutéž věc nazývat pokaždé jinak - a vlastně nemusí ani nazývat, může charakterizovat nepřímo, jaksi implicitně. To nám však nebrání Solovjovovy pojmy použít k popisu postav tohoto románu.

Ivan pro svůj převládající intelekt či racionalitu postrádá či potlačuje zbožnost, což se projevuje tím, že popírá Boží stvoření, vesmírnou harmonii. Rozhodně mu však nechybí ani stud, ani lítost - vždyt' právě jeho slitování s nevinnými dětmi nakonec otevírá ty nejhlubší a nejdůležitější otázky celého románu, otázky dobra a zla a svobody. Mít’ovi snad nechybí ani zbožnost ani lítost (také má slitování s dětmi a s chudáky ve svém snu, ostatně právě lítost a vztah $\mathrm{k}$ dětem jsou v Dostojevského díle lakmusovým papírkem povahy člověka). Co však Mítovi chybí, je stud. Často se opíjí, působí kolem sebe skandály. Starému Fjodoru Karamazovi chybí oba dva tyto city, stud i zbožnost, lítosti je však snad přece jen ještě schopen. Absenci zbožnosti nejlépe ukazuje scéna, v níž starý Karamazov vzpomíná na matku Aljoši a Ivana. Svým synům vypráví, jak poplival její ikonu. O absenci studu u něj není pochyb, Dostojevskij jej líčí jako „starého nestydu“ (старик-безобразник), kterého obklopovaly ženy lehkých mravů (безобразницы) a který se rád oddával orgiím s ženským pohlavím (безобразничать с женским полом любил). Použitá označení přitom spojuje ruské slovo bezobrazie (безобразие), které označuje cosi šeredného, ošklivého, ale také zvráceného, a je tak hodnocením estetickým i etickým, které však nepřímo označuje také jakousi bezbožnost, protože doslova znamená „bez obrazu“, tedy bez svatého obrazu, ikony (Jackson 1987: 304; Jackson 2013: 165). Ovšem ani Fjodor Karamazov není zcela ztracen, protože jeho syn Aljoša (a vlastně také starec Zosima) v něm stejně jako v ostatních umí probudit potlačený cit. Aljoša je př́íkladem člověka, kterému nechybí ani zbožnost, ani stud a ani lítost. Naopak zjevem až patologickým je Smerd'akov, který ztratil všechny tři tyto emoce a zdá se, jakoby ztratil vůbec schopnost cokoliv cítit, zůstala mu jen racionalita. 
Pokud bychom snad pochybovali o tom, co je a není správné, můžeme se v Dostojevského románech zorientovat podle toho, jaký osud jednotlivé postavy čeká. Smerd'akov nakonec spáchá sebevraždu, Ivan se v důsledku své př́lišné racionality, která mu znemožňuje uvěřit, psychicky zhroutí, Mítu jeho dřivější prostopášnosti přivedou před soud, i když jeho obvinění je zřejmě mylné. Starý Fjodor Karamazov je zavražděn Smerd’akovem, který je podle nejrůznějších náznaků jeho synem. Avšak Aljošovi starec Zosima předpovídá, že v hoři najde štěstí.

\section{Výrostek, absence zbožnosti a lítosti a špatná askeze}

Pro Solovjova jsou stud a z něj pramenící askeze prostředkem k dosažení celistvosti a neporušenosti osoby. Pokud však askeze není provázena lítostí a zbožností, může mít také jiné, nesprávné cíle. Formulaci takového cíle nalezneme např́iklad u voluntarismem ovlivněného solipsisty Ladislava Klímy v jeho díle $O$ Solovjevově etice. Klíma často zastává stanoviska až kontradiktorní k tvrzením Solovjova:

„My nazvali bychom askesí i zdržení se např. od četby, hudby, cestování a přemýšlení, vůbec zdržování se všeho možného za účelem cvičení a tužení vůle. (...) Daleko důstojnějším a důležitějším předmětem askeze bylo by cvičení se ve snášení tělesných bolestí, zimy, horka, štrapácí atd. (...) K jakému cíli tím budeš, jest otázka již druhotná, nebot' předně síla sama o sobě je svrchovanou ctností, sebeúčelem..." (Klíma 1993: 104$105)$.

Zatímco podle Klímy není cíl askeze důležitý, podle Solovjova tento cíl rozhoduje o tom, zda askeze bude dobrá či špatná, mylná. A zatímco Klíma chápe askezi jen jako cvičení, které posiluje člověka (myšlenku, že síla je ctnost, nalezl pro sebe jistě u Nietzscheho), pro Solovjova je askeze nutností a nemůže být $\mathrm{v}$ žádném př́ípadě samoúčelná. Podobně se askezí mučí také Arkadij v Dostojevského románu Výrostek. Nechybí mu tedy jistě pocit studu, který tuto askezi řídí. Je však schopen lítosti a zbožnosti?

„Když jsem si vymyslil ,svou ideu‘ (...), začal jsem zkoušet, zda jsem způsobilý ke klášteru a k askezi. Proto jsem byl celý první měsíc živ jen o chlebě a vodě. Smělo to být nejvýš dvě a půl libry černého chleba denně. Abych to dodržel, musel jsem klamat moudrého Nikolaje Semjonoviče a Marii Ivanovnu, která to se mnou dobře myslila. K její lítosti a k jistému údivu nadmíru taktního Nikolaje Semjonoviče jsem prosadil, že mi oběd nosili do pokoje. Tam jsem ho prostě ničil“ (Dostojevskij 2008: 85). 
V uvedené ukázce vidíme, co Arkadijova askeze způsobuje - lítost Marie Ivanovny, lež a především také plýtvání jídlem a jeho ničení. Chybí mu zde soucit i zbožnost, ale soucit se nakonec u Arkadije projevuje později ve vztahu k malé holčičce - Dostojevskij udělal opět prubířským kamenem charakteru vztah k trpícímu dítěti.

Kromě toho, že Arkadij působí skrze svou askezi cosi špatného, musí se touto askezí pořád zaobírat ve svých myšlenkách: „Touto otázkou jsem se zabýval v mysli dlouho a důkladně. Určil jsem si na př́klad, že někdy budu jíst dva dny za sebou jen chleba se solí, ale třetí den utratím, co jsem za dva dny ušetřil“" (Dostojevskij 2008: 8687). I to je znakem špatné askeze. Podle Solovjova je horší hřešit v mysli a vědomě než svými činy, ale nevědomě. Arkadijovi nevadí bezuzdně hodovat ani obírat se touto myšlenkou, pokud dodrží svůj plán. Solovjov také popisuje příběh dvou mnichů, kteří oba smilnili, když jednou opustili své poustevny. Zatímco jeden se hř́chem trápil a nepřestával na něj myslet, druhý si počínal, jako by se nic nestalo, a prožil zbytek života v poustevně v modlitbách. Ten, který na hřích stále myslel, nakonec podlehl hř́íchu znovu, zcela opustil ctnostný život a po smrti byl zatracen. Ten, který na hř́ich zapomněl, došel po smrti spasení a s jeho tělem se stal zázrak. Tím se Solovjov snaží podpořit své tvrzení, že myšlenky na hřích vedou $\mathrm{k}$ hříšnému životu a že samotný hřích není tak špatný, pokud není vědomý či pokud na něj nemyslíme do konce života. Proto Arkadijova askeze, které vede k myšlenkám na jídlo, na hodování a také $\mathrm{k}$ racionalizacím, není dobrou askezí.

Jak jsme naznačili výše, opodstatněnost askeze můžeme posoudit podle toho, jakému účelu tato askeze slouží. Arkadijova askeze má sloužit k dosažení jeho ideje, není tedy zcela samoúčelná. Jaká však je sama tato idea? Zdá se, že idea spočívá v rothschildovském bohatství, ale to není její konečný cíl. I toto bohatství má něčemu sloužit; Arkadij se jej chce vzdát a dokázat si tak, že je svobodný, chce se osvobodit a zároveň být jakýmsi pánem svobody. Jinými slovy, Arkadij si hraje na Boha. A právě to odpovídá na naši otázku; Arkadijovi totiž chybí zbožnost. Jeho svoboda je falešná, idea temná a jeho askeze je špatná. V závěru však svou ideu přehodnotí, nebot’ on už zpět do temnoty nechce, je rád mezi lidmi. Dodejme, že Arkadij rozhodně není záporná postava, ostatně Dostojevského chápání dobra a zla není černobílé a téměř žádná z postav není ve skutečnosti zlá. Arkadij se pouze vyvíjí.

\section{Dvě legendy a falešná zbožnost}

Vrcholným př́kladem toho, že ani jedna ze tř́i zakládajících emocí nesmí mravnému člověku chybět, je legenda o Velkém inkvizitorovi v Dostojevského románu Bratři Karamazovi. Postupně se dozvídáme, že Inkvizitor v této legendě byl velký asketa, který 
se v poušti živil kořínky a porazil svou tělesnost, nechyběl mu tedy jistě stud. Jak už jsme uvedli výše, stud samotný však nestačí a bez ostatních emocí může vést ke špatné askezi. Solovjov udává příklad z historie, který je legendě odehrávající se ve španělské Seville blízký:

„Nadvláda asketického principu (...) vede $\mathrm{k}$ děsivým důsledkům. Představitelé středověké církve, kteří mučili a upalovali kacíře, Židy, čaroděje a čarodějnice, byli povětšinou lidé $\mathrm{z}$ asketického hlediska nenapadnutelní, ale jednostranná moc ducha z nich při absenci lítosti učinila ztělesněné d'ábly“" (Solovjov 2002: 56-57).

O Inkvizitorovi se však dozvídáme, že mu nechybí ani soucit. Vše, co dělá, dělá z lítosti vičč člověku; bere proto na sebe všechnu zodpovědnost, svobodu i hř́ích, aby jich ušetřil člověka, tím však činí člověka nesvobodným (Berd’ajev 1998: 282-288). Znemožňuje mu vykonat zlo, ale tím mu také znemožňuje vykonat dobro. Inkvizitor opět zbožštuje sám sebe, když se snaží lidem vzít to, co jim dal Bůh - svobodu. To, co postrádá, je tedy opět zbožnost, zbožná úcta k tomu, co člověka převyšuje. Aljoša správně odhaluje, že Inkvizitor má tajemství - nevěrí v Boha. Namísto následování boholidského ideálu zde stojí ztělesnění člověkobožství.

Solovjov se Dostojevského legendou (či snad poemou Ivana Karamazova) inspiroval a ve stejném duchu napsal součást svých Tř́ rozhovorů, totiž Krátkou legendu o Antikristu. I když kulisy jsou odlišné, témata jsou totožná; kritika těch, kdo zapomněli ve své viŕre na Krista, člověkobožství (či téma nadčlověka), otázka svobody atd. Oproti Dostojevského legendě se v té Solovjovově objevuje navíc jeden originální, dramatický prvek. Solovjov nám popisuje nadčlověka, který je stejně jako inkvizitor asketický, je také soucitný, je to totiž filantrop a vegetarián, což jsou postoje, kterých si Solovjov velmi vážil. Nakonec jej však vykresluje jako velmi zbožného člověka, který dokonce sjednocuje církve. Právě snaha o sjednocování církví byla neoddělitelnou součástí Solovjovova světonázoru. Čtenář je tak udržován do poslední chvíle v napětí a netuší, že pod maskou tohoto člověka se skrývá antikrist, který kolem sebe nakonec rozsévá jen smrt. Jak ale může být antikristem někdo, kdo je asketický, kdo je altruista a kdo je zbožný? Někdo, komu nechybí ani jeden ze tří citů, zakládajících morálku? Právě na tom je založen dramatický zvrat Solovjovovy legendy; zbožnost nadčlověka byla jen falešná. Tento nadčlověk totiž respektoval církev a věřil v ni, nevěřil ale v Boha a zřekl se Krista. 


\section{Závěr}

Podobně bychom mohli analyzovat i další postavy v Dostojevského dílech. Většina z nich postrádá právě zbožnost, např́klad Kirillov z Běsů, který má rád děti, je soucitný a žije prostě, ale podlehne omylu při hledání svobody. Ostatně právě tato postava formuluje v románu explicitně teorii člověkobožství. Blízká této teorii je i dvojí morálka Rodiona Raskolnikova v románu Zločin a trest, ostatně téma dvojí morálky se objevuje v mnohých Dostojevského dílech (Bulgakov 1998: 264). Rodion je další z postav, které nechybí soucit, ovšem chybí mu zbožnost a zřejmě také stud. V Dostojevského románech však najdeme také postavy, kterým chybí i jiné emoce, např́íklad soucit. Takové jsou především některé postavy Běsư (např́iklad Stavrogin, Verchovenskij), které ztratily schopnost litovat ostatní a některé z nich dokonce ztratily i schopnost litovat samy sebe. Lítost, ale i zbožnost postrádá zřejmě také Rogožin v románu Idiot, což může čtenář odhalit při jeho rozpravě s knížetem Myškinem nad obrazem mrtvého Krista.

Mohli bychom analýzu rozšiŕit i na další postavy nebo hlouběji prozkoumat uvedené případy, to by však přesahovalo rozsah této studie. Naším cílem však nebylo podat vyčerpávající přehled př́íkladů daného jevu, které můžeme v Dostojevského díle najít. Cílem bylo představit a vysvětlit Solovjovovu teorii morálních základů. Doufáme, že zvolené př́ḱlady ji pomohly vykreslit jako realistickou a na psychologii vystavěnou teorii.

\section{Summary}

The present article introduces the moral foundations theory by Russian philosopher V. S. Solovyov. It shows that three emotions are in the foundations of morality: shame, pity, and reverence. Morality is conditioned by the presence of all three emotions in man, then, a person who lacks any of these emotions is not acting morally. In the current article, a few examples - based on novels by F. M. Dostoevsky - are provided to demonstrate what the shortage of these emotions can cause. The analyzed material is taken from The Brothers Karamazov and The Adolescent.

\section{Резюме}

Приведенная статья представляет теорию основ морали, созданную русским философом В. С. Соловьевым. В статье указано, что в основе морали лежат три эмоции: стыд, жалость и благоговение. Мораль обусловлена наличием в человеке всех трех эмоций, поэтому человек, которому не хватает этих эмоций, не может 
действовать, исходя из моральных соображений. В данной статье приведено несколько примеров, основанных на романах Ф. М. Достоевского, для демонстрации того, к чему может привести отсутствие этих эмоций. Анализируемый материал взят из «Братьев Карамазовых» и «Подростка».

\section{Literatura}

Berd'ajev, N. A. Dostojevského pojetí světa. Praha: OIKOYMENH, 2000.

Brabec, J. Vladimír Solovjov a Pierre Teilhard de Chardin: Idea vývoje a komplexní vědy. In: Demjančuková, D. (ed.) Ruská kultura 20. století. Plzeň: Západočeská univerzita v Plzni, 2008, s. 55-78.

Bulgakov, S. N. Ivan Karamazov jako filozofický typ. In: Velký inkvizitor: Nad textem F. M. Dostojevského. Olomouc: Aletti Velehrad-Roma, 1998, s. 239-273.

Dostojevskij, F. M. Běsi. Praha: Academia, 2000.

Dostojevskij, F. M. Brat'a Karamazovy. Moskva: Sovremennik, 1981.

Dostojevskij, F. M. Idiot. Praha: Odeon, 1968.

Dostojevskij, F. M. Výrostek. Praha: KMa, 2008.

Dostojevskij, F. M. Zločin a trest. Praha: Svět sovětů, 1966.

Haidt, J. The Righteous Mind. New York - Toronto: Random House, 2012.

Jackson, R. L. Close Encounters. Essays on Russian Literature. Boston: Academic Studies Press, 2013.

Jackson, R. L. The Art of Dostoevsky. Deliriums and Nocturnes. New Jersey: Princeton University Press, 1987.

Kautman, F. Fjodor Michajlovič Dostojevskij. Věčný problém člověka. Praha, Academia, 2004.

Klíma, L. O Solovjevově etice. Praha: Lege Artis, 1993.

Kostalevsky, M. Dostoevsky and Soloviev. The Art of Integral Vision. New Haven: Yale University, 1997.

Platón. Faidros. Praha: OIKOYMENH, 2014.

Platón. Ústava. Praha: OIKOYMENH, 2014.

Prokof'ev, A. V. Koren vsej nravstvennoj žizni čeloveka (moral'naja filosofija Vladimira Solovjova i problema styda). Istorija filosofii. 2017 (22), s. 38-52. 
Solovjov, V. S. Čtenija o bogočelovečestve. Moskva: Izdatel'stvo AST, 2004.

Solovjov, V. S. Idea nadčlověka. Olomouc: Votobia, 1997a.

Solovjov, V. S. Opravdanije dobra: nravstvennaja filosofija. Moskva: Akademičeskij projekt, 2010.

Solovjov, V. S. Ospravedlnění dobra. Olomouc: Refugium Velehrad-Roma, 2002.

Solovjov, V. S. Tři rozhovory: o válce, pokroku a konci světových dějin obsahujicí krátkou legendu o Antikristu a několik menšich přiložených statí. Praha: Zvon, 1997b.

Solovyov, V. S. The Justification of the Good. London: Constable and Company Ltd., 1918. 